\title{
Prograde and retrograde evolution of eclogites from the Bantimala Complex in South Sulawesi, Indonesia
}

\author{
Nugroho Imam SetiaWAN*, Yasuhito OsAnAI ${ }^{* *}$, Nobuhiko NAKANO**, Tatsuro AdAchi**, \\ Kazuhiro YonemurA ${ }^{* * *}$ and Aya Yoshimoto** \\ ${ }^{*}$ Geological Engineering Department, Faculty of Engineering, Gadjah Mada University, Yogyakarta 55281, Indonesia \\ ${ }^{* *}$ Division of Earth Sciences, Faculty of Social and Cultural Studies, Kyushu University, Fukuoka 819-0395, Japan \\ ${ }^{* * * *}$ Metals Exploration Department, Japan Oil, Gas and Metals National Corporation (JOGMEC), \\ Minato-ku, Tokyo 105-0001, Japan
}

\begin{abstract}
This contribution reports the metamorphic evolution of the high-pressure metamorphic rocks from the Bantimala Complex, South Sulawesi, Indonesia. Barroisite-bearing and barroisite-free eclogites were examined to assess their metamorphic evolutions, which have implications regarding the tectonic conditions in this region. The eclogites mainly consist of garnet, omphacite, phengite, rutile, and epidote, with or without barroisite. The variations in mineral assemblages are interpreted to depend upon local changes in the bulk chemical composition. The barroisite-bearing eclogites contain two types of euhedral garnet: coarse- $(1-1.5 \mathrm{~mm})$ and finegrained $(<0.5 \mathrm{~mm})$. Mineral inclusions in the coarse-grained garnet core and mantle show epidote + titanite and glaucophane + epidote assemblages, that stabilized at $0.9-1.5 \mathrm{GPa}$ and $350-550{ }^{\circ} \mathrm{C}$ within epidote blueschist-facies conditions. Mineral chemistry and chemical-mapping analyses indicate that both fine-grained garnet and the rim of coarse-grained garnet formed at peak $P-T$ conditions, which were estimated as $2.3-2.7 \mathrm{GPa}$ at 615-680 ${ }^{\circ} \mathrm{C}$ based on the garnet-omphacite-phengite-quartz equilibrium. Peak $P-T$ conditions for barroisitefree eclogite were similar (2.5-2.7 GPa at $\left.650-690{ }^{\circ} \mathrm{C}\right)$ to those for barroisite-bearing eclogite. Actinolite rims overgrowing matrix sodic-calcic amphiboles attest to retrogression at $P<0.5 \mathrm{GPa}$ and $T<350{ }^{\circ} \mathrm{C}$ in a clockwise $P-T$ path. The very low geothermal gradient experienced during the prograde path $\left(\sim 5^{\circ} \mathrm{C} / \mathrm{km}\right)$ likely suggests the subduction of an old and cold oceanic crust. The low geothermal gradient on the retrograde path suggests decompressional cooling during exhumation, possibly favored by a serpentinite-dominated matrix within a subduction channel environment.
\end{abstract}

Keywords: High-pressure metamorphic rocks, Eclogite, Metamorphic evolution, Bantimala Complex, South Sulawesi

\section{INTRODUCTION}

High-pressure (HP) metamorphic rocks related to a Cretaceous subduction complex are widely distributed throughout Central Java, Sulawesi, and South Kalimantan (Indonesian Borneo) (Miyazaki et al., 1996, 1998; Parkinson, 1998; Parkinson et al., 1998; Kadarusman and Parkinson, 2000; Kadarusman et al., 2007). Deciphering the prograde and retrograde pressure-temperature $(P-T)$ paths of these HP rocks provides important constraints on the tectonic and geodynamic evolutions in central Indonesia. The peak metamorphic conditions of HP metamorphic rocks (i.e.,

doi: $10.2465 /$ jmps. 150907

N.I. Setiawan, nugroho.setiawan@ugm.ac.id Corresponding author eclogite and garnet-glaucophane rocks) from the Bantimala Complex in South Sulawesi have been reported to be $1.8-2.4 \mathrm{GPa}$ at $580-640{ }^{\circ} \mathrm{C}$, and retrogressed to 1.0 $\mathrm{GPa}$ at $350{ }^{\circ} \mathrm{C}$ and $0.5 \mathrm{GPa}$ at $350{ }^{\circ} \mathrm{C}$ (Miyazaki et al., 1996). Ultrahigh-pressure metamorphism has also been reported from this area for garnet-jadeite-quartz rocks $\left(P>2.7 \mathrm{GPa}\right.$ at $T=720-760{ }^{\circ} \mathrm{C}$ ) (Parkinson et al., 1998). However, detailed reconstruction of the prograde and retrograde $P-T$ paths of these HP metamorphic rocks is still lacking, owing to intense retrograde overprinting and fluid related metasomatic alteration. In particular, previous studies (Miyazaki et al., 1996; Parkinson et al., 1998) did not estimate the prograde $P-T$ paths.

In this study, we present new observational results of HP metamorphic rocks that preserve textural informa- 


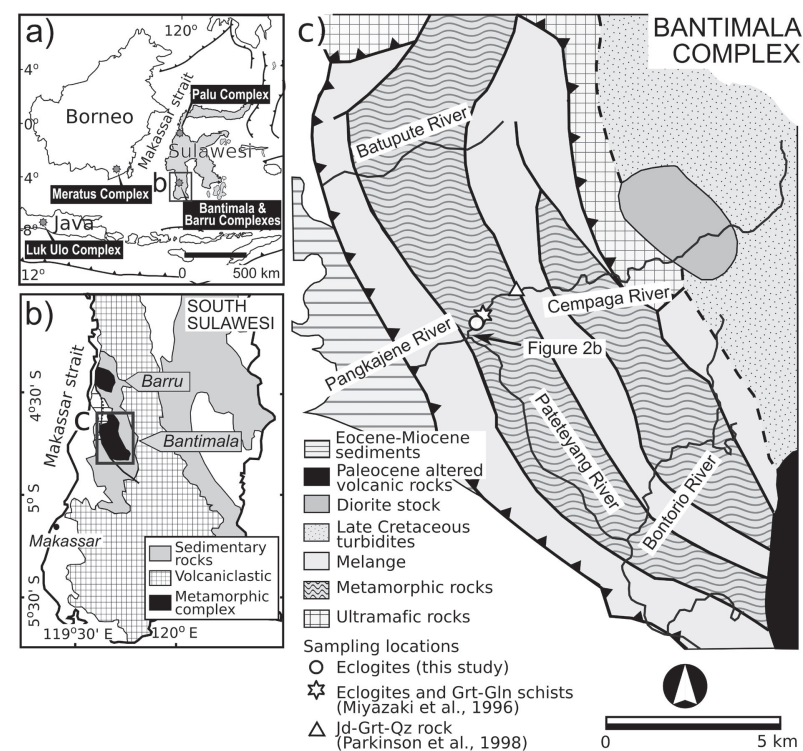

Figure 1. (a) Distribution of high-pressure metamorphic rocks related to the Cretaceous subduction complex in central Indonesia. (b) Location and (c) simplified geological map of the Bantimala Complex in South Sulawesi (modified after Sukamto, 1982) with sampling locations from this study and previous studies.

tion on prograde, peak, and retrograde stages, and estimate their $P-T$ paths. Our results and their tectonic implications are then compared to other terranes in central Indonesia. Mineral abbreviations in this paper follow Whitney and Evans (2010).

\section{GEOLOGICAL OUTLINE}

Remnants of a Cretaceous subduction system are distributed throughout central Indonesia, and include Central Java (Luk Ulo Complex), South Kalimantan (Meratus Complex), and South Sulawesi (Bantimala and Barru Complexes) (Fig. 1a). The study area (South Sulawesi) predominantly comprises sandstone, shale, chert, basalt, dunite, lherzolite, serpentinite, and various metamorphic rocks ranging from low grade to eclogite-facies conditions (Sukamto, 1982; Wakita et al., 1994, 1996; Miyazaki et al., 1996; Parkinson et al., 1998) (Fig. 1b). The aforementioned metamorphic complexes have been interpreted as terranes formed by a single northwesterly Cretaceous subduction beneath Sundaland (Parkinson et al., 1998), and then dismembered during the opening of the Makassar Strait (Hamilton, 1979) (Fig. 1a).

In South Sulawesi, rocks belonging to this system occur in the Bantimala and Barru Complexes (Fig. 1b). The Bantimala Complex is a tectonic stack of slices mainly consisting of various sedimentary rocks, ultramafic rocks, metabasites, and metapelites with ages ranging from Jurassic to middle Cretaceous (Sukamto, 1982;
Wakita et al., 1994, 1996; Miyazaki et al., 1996; Parkinson et al., 1998). The metamorphic rocks mainly occur within a mélange unit. To the west, this unit overthrusts the Eocene-Miocene sediments, whereas to the north and east it is bounded by ultramafic rocks later intruded by diorite stocks (Sukamto, 1982; Fig. 1c). The HP rocks are commonly found as loose blocks along the courses of the Pangkajene, Bontorio, Cempaga, Pateteang, and Bantimala rivers (Fig. 1c). Several of them (eclogite and garnet-glaucophane rocks) occur as tectonic blocks within sheared serpentinites. The blocks mainly consist of mafic rocks (glaucophane-bearing eclogitic schists, eclogites, and glaucophane schists), and to a lesser extent pelitic rocks (garnet-glaucophane-quartz schist). More rare boulders of garnet-jadeite-quartz rocks are also described in this region (Parkinson et al., 1998).

Along the Cempaga River, eclogite blocks occur as rounded boulders about 1-2 $\mathrm{m}$ in diameter (Figs. 2b-2d). Figure 2 is available online from http://doi.org/10.2465/ jmps.150907. In this area, the exposed bedrock mainly consists of glaucophane schist (Fig. 2a) with variation of epidote-, quartz-, and chlorite-rich layers, but no eclogite as bedrock was found in this place. Despite that, the rather large size of the boulders (Fig. 2c) suggests a proximal provenance. The eclogite samples $(310 \mathrm{~T} 03 \mathrm{~F}$ and 310T03A2) were collected approximately $200 \mathrm{~m}$ north of the triple junction between the Pateteang, Pangkajene, and Cempaga Rivers (Fig. 1c).

$\mathrm{K}$-Ar phengite datings of the eclogites and garnetglaucophane rocks from the Bantimala Complex yielded ages ranging from $113 \pm 6$ to $137 \pm 3 \mathrm{Ma}$, interpreted as exhumation ages (Wakita et al., 1994, 1996; Parkinson et al., 1998).

\section{PETROGRAPHY}

Two eclogite samples, 310T03F and 310T03A2, were selected for petrographic and mineral chemistry analyses and represent barroisite-bearing and barroisite-free eclogites, respectively.

\section{Barroisite-bearing eclogite}

The eclogite of interest predominantly comprises garnet, omphacite, sodic-calcic amphibole, phengite, and rutile, with subordinate amounts of epidote and quartz in the matrix (Figs. 3a-3c). Retrograde hematite is rarely found in the matrix (Fig. 3d) near the rim of a garnet crack. Two types of garnet can be distinguished: coarse-grained (1$1.5 \mathrm{~mm}$ in diameter) and fine-grained $(<0.5 \mathrm{~mm}$ in diameter) (Figs. 3a-3f). Coarse-grained garnet, being in direct contact with omphacite and phengite, preserves its euhe- 


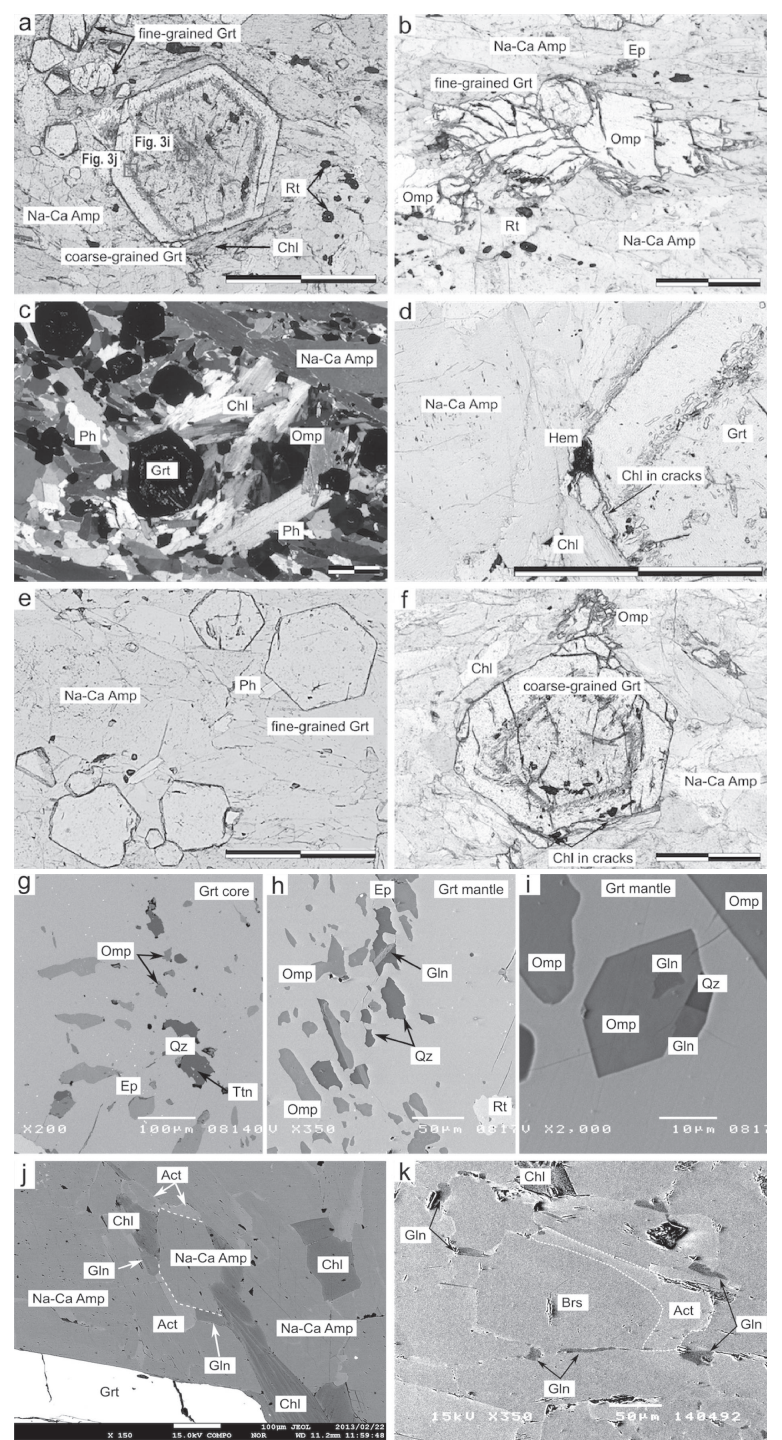

Figure 3. Photomicrographs and back-scattered electron images of barroisite-bearing eclogite. Scale-bars correspond to $1 \mathrm{~mm}$, except for back-scattered images. (a) Euhedral coarse-grained garnet, fine-grained garnet, and rutile embedded in $\mathrm{Na}-\mathrm{Ca}$ amphiboles. (b) Granoblastic omphacite adjacent to fine-grained garnet. Other minerals such as rutile, $\mathrm{Na}-\mathrm{Ca}$ amphibole, and epidote are also present. (c) Garnet, omphacite, phengite, and $\mathrm{Na}-\mathrm{Ca}$ amphibole are common minerals in the studied eclogite (crossed-polarized light). (d) Retrograde hematite is present in the matrix near the garnet cracks. (e) Well-formed crystal faces of fine-grained garnet in direct contact with phengite. (f) Rim portion of garnet in direct contact with clinopyroxene still preserves an idiomorphic habitus, whereas others are replaced by secondary chlorite. (g) Omphacite, epidote, quartz, and titanite included in the garnet core portion (back-scattered image). (h) Omphacite, epidote, quartz, glaucophane, and rutile included in the garnet mantle (back-scattered image). (i) Glaucophane inclusion in the garnet mantle. The glaucophane is surrounded by omphacite and in contact with quartz (back-scattered image). (j) and (k) $\mathrm{Na}-\mathrm{Ca}$ amphibole (barroisite) partly rimmed by glaucophane and surrounded by actinolite (back-scattered electron images). Color version is available online from http://doi.org/ 10.2465/jmps. 150907 .
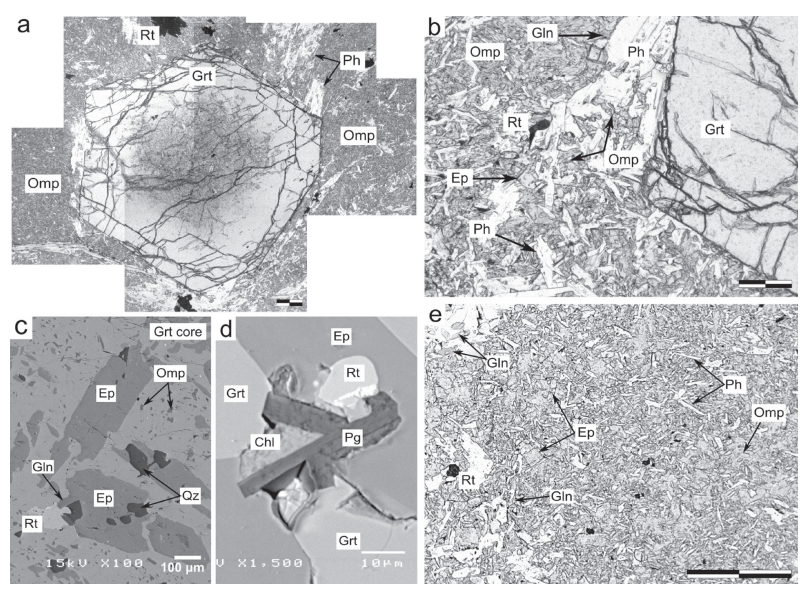

Figure 4. Photomicrographs and back-scattered electron images of the barroisite-free eclogite. Scale-bars correspond to $1 \mathrm{~mm}$, except for the back-scattered images. (a) Coarse-grained garnet is crowded with fine-grained inclusions in the core portion. (b) The matrix consists of omphacite, phengite, rutile, and subordinate amounts of glaucophane and epidote. (c) and (d) epidote, rutile, quartz, glaucophane, omphacite, chlorite, and paragonite included in the garnet core portion. (e) Coarse-grained omphacite in the matrix is crowded with fine-grained phengite, epidote, and glaucophane. Color version is available online from http://doi.org/10.2465/jmps. 150907 .

dral shape (Figs. 3e and 3f). The coarse-grained garnet has textural zoning with numerous mineral inclusions in the core and mantle, whereas that at the rim is inclusion-free (Fig. 3a). The major inclusion minerals are omphacite, sodic-calcic amphibole, epidote, glaucophane, chlorite, and quartz (Figs. 3g-3i). Titanite inclusions $(0.5 \mu \mathrm{m})$ are rare, and only observed in the core of coarse-grained garnet (Fig. 3g). Conversely, rutile, which is not found as inclusions in the core, is present in the mantle of coarse-grained garnet (Fig. 3h). Glaucophane is included in omphacite, which is also included in the mantle of coarse-grained garnet (Fig. 3i). Meanwhile, inclusions in fine-grained garnet are relatively rare. In the matrix, interstitial glaucophane typically overgrows nematoblastic sodic-calcic amphiboles (Figs. $3 \mathrm{j}$ and $3 \mathrm{k}$ ). Both the amphiboles are rimmed by thin actinolite (Figs. $3 \mathrm{j}$ and $3 \mathrm{k}$ ). Retrograde chlorite is abundant in this sample, and occurs as coarse-grained lepidoblastic crystals in the matrix (Fig. 3c) or as secondary chlorite filling cracks of other minerals (Figs. $3 \mathrm{~d}$ and $3 \mathrm{f}$ ). Abite commonly occurs as crack-filling material in garnet, omphacite, phengite, and sodic-calcic amphibole.

\section{Barroisite-free eclogite}

The barroisite-free eclogite displays a poikiloblastic texture and predominantly comprises garnet, omphacite, phengite, and rutile, with minor epidote, glaucophane, and quartz in the matrix (Figs. 4a and $4 b$ ). The garnet oc- 
curs as euhedral, coarse-grained crystals $(\sim 1 \mathrm{~cm})$, and has an inclusion-rich core (Fig. 4a). The inclusions in the garnet core are omphacite, glaucophane, rutile, paragonite, chlorite, and quartz (Figs. 4c and 4d). Coarse-grained omphacite $(\sim 5 \mathrm{~mm})$ contains many inclusions, which are fine-grained epidote, phengite, and glaucophane (Fig. $4 \mathrm{e})$. A subsequent stage of retrograde overprinting is suggested by chlorite and albite along the fractures of garnets.

\section{MINERAL CHEMISTRY}

Mineral chemistry was measured using a scanning electron microscope with an energy dispersive X-ray analytical system (EDS) (JEOL JSM 5301S-JED 2140) and an electron probe microanalyzer with a 5-channel wavelength dispersive X-ray analytical system (WDS) (JEOL JXA-8530F) at Kyushu University. The quantitative analyses of minerals were performed with a $15 \mathrm{kV}$ accelerating voltage, $0.4 \mathrm{nA}$ probe current for EDS, and $12 \mathrm{nA}$ and $2 \mu \mathrm{m}$ probe diameter for WDS. The results were processed with the ZAF correction method. Representative analyses of mineral chemistry are shown in Tables 1-3. The analytical conditions of $\mathrm{X}$-ray mapping included a $15 \mathrm{kV}$ accelerating voltage and $50 \mathrm{nA}$ probe current.

\section{Garnet}

Representative analyses of garnet in the two selected eclogite samples are given in Table 1 . The $\mathrm{Fe}^{3+}$ contents of garnet were calculated using algorithms proposed by Droop (1987). As mentioned before, two types of garnet were recognized in the barroisite-bearing eclogite, and both of them were mapped for $\mathrm{Y}, \mathrm{Mg}, \mathrm{Mn}$, and $\mathrm{Ca}$ (Figs. $5 \mathrm{a}-5 \mathrm{~h})$. The boundary between the core and mantle of coarse-grained garnet is clearly defined by $\mathrm{Mn}$ and $\mathrm{Ca}$ concentrations (Figs. 5e and 5g), while the boundary between the mantle and rim is defined by the abundance of Y (Fig. 5a). On the other hand, fine-grained garnet shows a very low concentration of Y (Fig. 5b). The zoning pattern in fine-grained garnet is clearly defined by $\mathrm{Mg}$, $\mathrm{Mn}$, and $\mathrm{Ca}$ concentrations (Figs. 5d, 5f, and 5h). Y was selected to define the initial zonation of garnet because it is generally considered to be relatively immobile during metamorphism (Lanzirotti, 1995; Cheng et al., 2007).

In general, the coarse-grained garnet core $\left(\mathrm{Alm}_{49-63}\right.$ $\mathrm{Sps}_{4-14} \operatorname{Prp}_{7-10} \mathrm{Grs}_{26-31}$ ) has higher spessartine, slightly higher grossular, and lower pyrope contents compared to the mantle, whereas the almandine contents are approximately the same in the core and the mantle $\left(\mathrm{Alm}_{50-64}\right.$ $\mathrm{Sps}_{2-4} \operatorname{Prp}_{8-20} \mathrm{Grs}_{21-27}$ ). Detailed observations using chemical mapping show that the coarse-grained garnet core has clear Mn zoning (Fig. 5e). Pyrope and grossular compo- nents also show zonation from core to mantle (Figs. 5c, 5g, and 6a). The almandine component shows complex and continuous zonation from core to mantle (Fig. 6a; available online from http://doi.org/10.2465/jmps.150907). The coarse-grained garnet rim shows higher pyrope contents compared to the core and mantle (Figs. 5c and 6a). The rims can be divided into two zones, rims I and II, from the more internal to the more external portion. Rim I has higher spessartine and grossular and lower pyrope contents ( $\left.\mathrm{Alm}_{47-52} \mathrm{Sps}_{4-9} \operatorname{Prp}_{15-23} \mathrm{Grs}_{23-28}\right)$ compared to rim II $\left(\mathrm{Alm}_{48-50} \mathrm{Sps}_{2-3} \operatorname{Prp}_{27-30} \mathrm{Grs}_{20-21}\right)$ (Fig. 6a). The zoning patterns from mantle to rim show that almandine, pyrope, and spessartine components have discontinuous zonation or have steep increases or decreases (Fig. 6a).

Compositional variations of the coarse-grained garnet rim are very similar to the zonation of fine-grained garnet (Figs. 5c-5f, 6a, and 6b). The fine-grained garnet can be divided into two zones, core and rim, based on the $\mathrm{Mg}$ zonation (Fig. 5d). The core of fine-grained garnet (Alm $46-51$ $\mathrm{Sps}_{3-11} \operatorname{Prp}_{16-22} \mathrm{Grs}_{24-29}$ ) correlates with rim I of the coarsegrained garnet (Figs. 5c-5f). Similarly, the rim of finegrained garnet $\left(\mathrm{Alm}_{47-51} \mathrm{Sps}_{2-4} \operatorname{Prp}_{25-27} \mathrm{Grs}_{19-24}\right)$ correlates with rim II of the coarse-grained garnet (Figs. 5c-5f). Portions of the garnet outer rim (Fig. 5d) that are in contact with chlorite show increasing $\mathrm{Fe}^{2+} /\left(\mathrm{Fe}^{2+}+\mathrm{Mg}\right)$ ratios (Table 1 and Figs. 6a, and 6b) (Alm $\left.{ }_{47-55} \mathrm{Sps}_{4-6} \operatorname{Prp}_{15-20} \mathrm{Grs}_{22-25}\right)$. However, the outer rim occurs locally, and many garnet grains do not show this chemical characteristic.

Garnet in the barroisite-free eclogite shows weak chemical zonation compared to that in the barroisitebearing eclogite (Fig. 6c). Spessartine, almandine, and grossular are higher in the core $\left(\mathrm{Alm}_{59-62} \mathrm{Sps}_{3-5} \operatorname{Prp}_{9-14}\right.$ $\left.\mathrm{Grs}_{23-28}\right)$, and spessartine is depleted at the rim $\left(\mathrm{Alm}_{55-57}\right.$ $\mathrm{Sps}_{1-3} \operatorname{Prp}_{18-20} \mathrm{Grs}_{23-25}$ ).

\section{Clinopyroxene}

The atomic fraction of clinopyroxene was calculated based on six oxygens, and the mole fractions of end members were calculated as suggested by Okamoto et al. (2000). $\mathrm{Fe}^{2+} / \mathrm{Fe}^{3+}$ ratios were determined from stoichiometry using the method of Ryburn et al. (1976) as $\mathrm{Fe}^{3+}=4-$ $2 \mathrm{Si}-2 \mathrm{Ti}-\mathrm{Al}-\mathrm{Cr}+\mathrm{Na}+\mathrm{K}, \mathrm{Fe}^{2+}=\mathrm{Fe}$ total $-\mathrm{Fe}^{3+}$. Representative analyses are given in Table 1. Clinopyroxene in the barroisite-free eclogite is an omphacite; the matrix omphacite and omphacite inclusions in garnet have slightly different compositions (Fig. 7a; available online from http://doi.org/10.2465/jmps.150907). Omphacites in the matrix have a homogeneous composition with slightly higher augite and lower acmite components ( $\operatorname{Aug}_{35-52}$ $\left.\mathrm{Jd}_{39-46} \mathrm{Acm}_{4-14}\right)$ compared to omphacite inclusions in the garnet core $\left(\mathrm{Aug}_{35-46} \mathrm{Jd}_{39-50} \mathrm{Acm}_{11-23}\right)$ (Fig. 7a). General- 


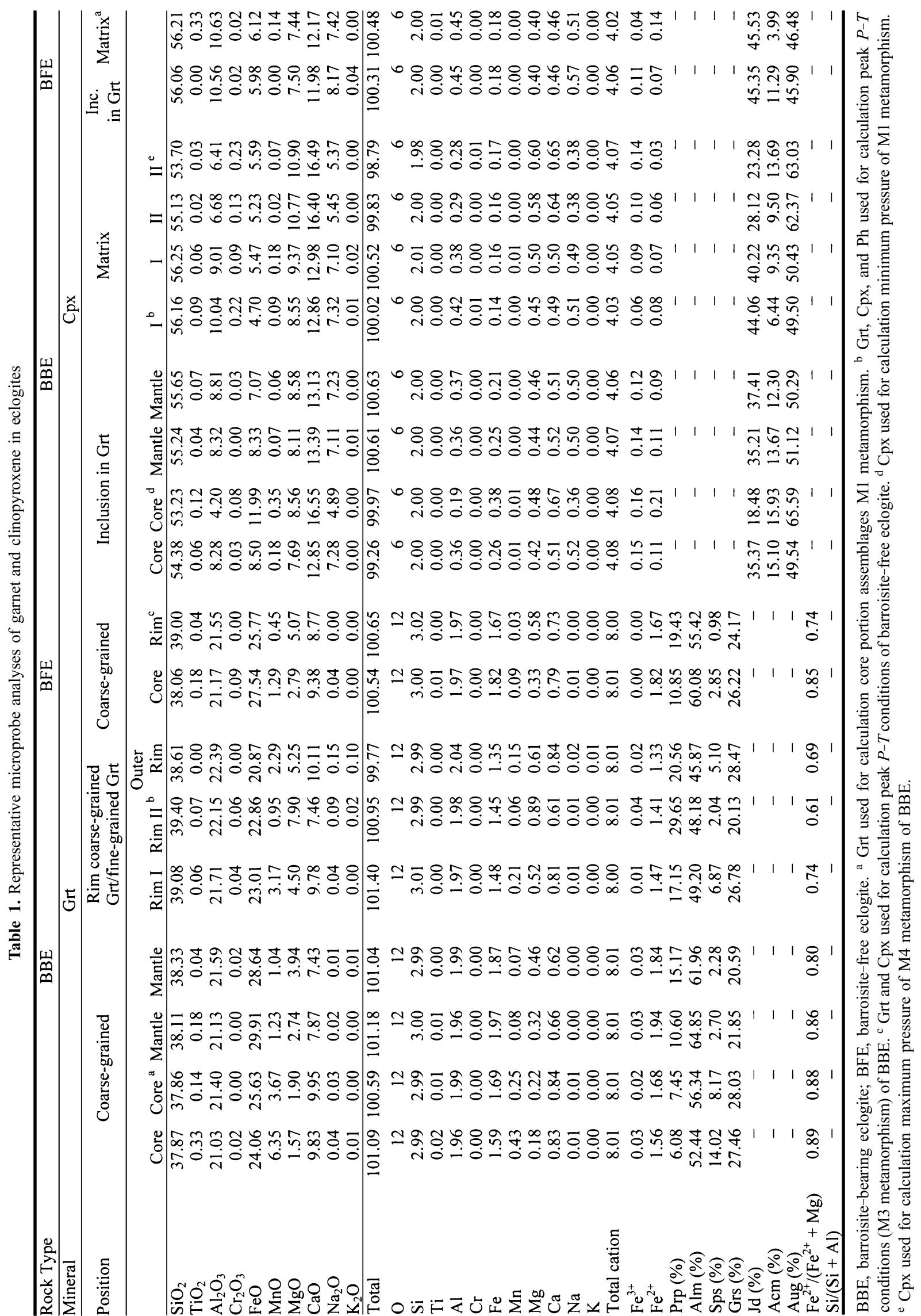



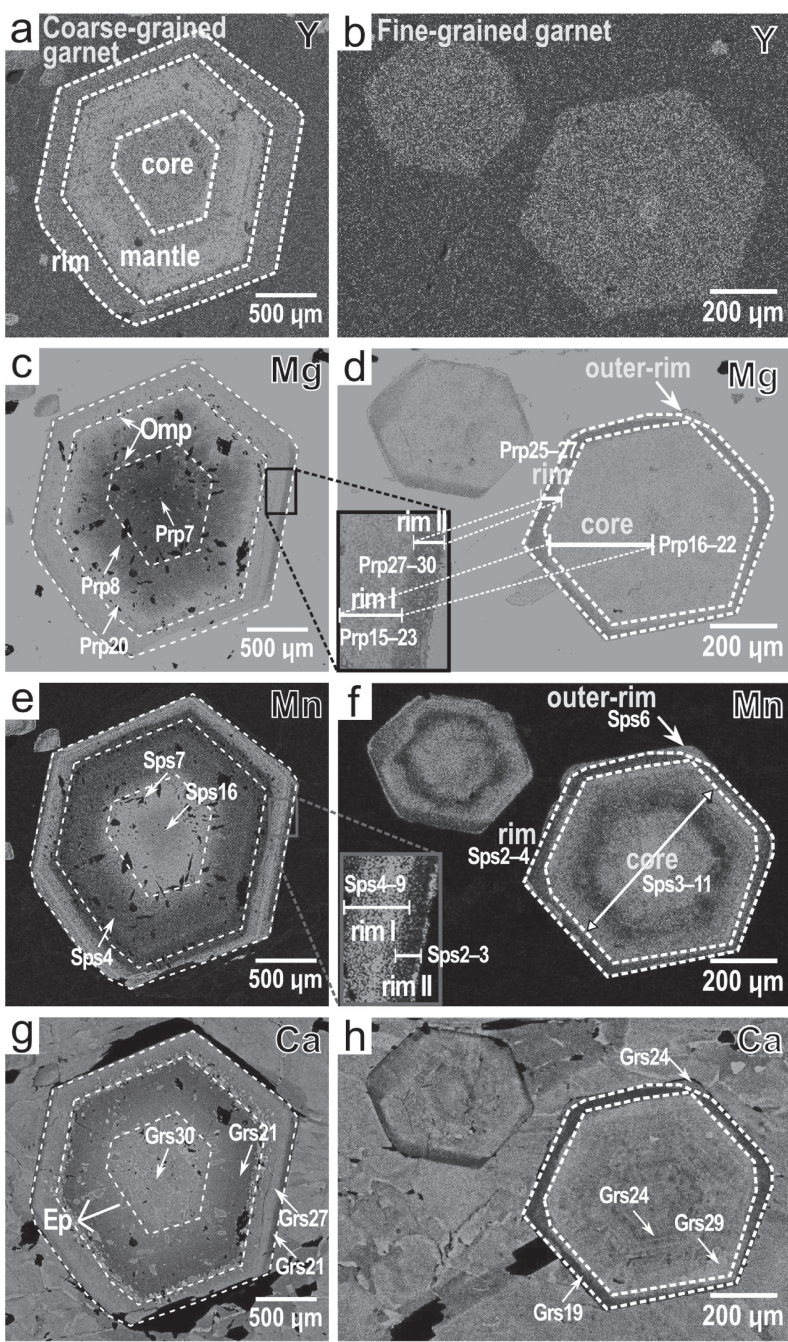

Low

X-ray intensity

High

Figure 5. X-ray maps of the $\mathrm{Y}, \mathrm{Mg}, \mathrm{Mn}$, and Ca of coarse-grained (a), (c), (e), and (g) and fine-grained garnets (b), (d), (f), and (h) in the barroisite-bearing eclogite. (a) The chemical zonation of core-mantle-rim coarse-grained garnet is clearly defined by the $\mathrm{Y}$ zonation. (b) Fine-grained garnet shows a flat $\mathrm{Y}$ zonation pattern. (c) The Mg composition of coarse-grained garnet gradually increases from core to rim. The rim of coarse-grained garnet and the $\mathrm{Mg}$ zonation of fine-grained garnet (d) are similar, indicating that (i) rim I coarse-grained garnet is similar to the core of fine-grained garnet, and (ii) rim II coarse-grained garnet is similar to the rim of fine-grained garnet. (e) Mn composition of the coarse-grained garnet decreases from the core to the mantle and slightly increases in the rim. More detailed observation of the rim portion suggests the Mn composition is decreasing from rim I to rim II of the coarse-grained garnet, which is similar to the fine-grained garnet (f). (g) Ca composition in the coarse-grained garnet gradually decreases from the core to the mantle, increases at rim I, and finally decreases again at rim II. The mineral inclusions with high $\mathrm{X}$-ray intensity (red color) in the coarse-grained garnet are epidotes. (h) The chemical characteristics of the rim of coarse-grained garnet are similar to those of fine-grained garnet. Color version is available online from http://doi.org/10.2465/jmps. 150907.
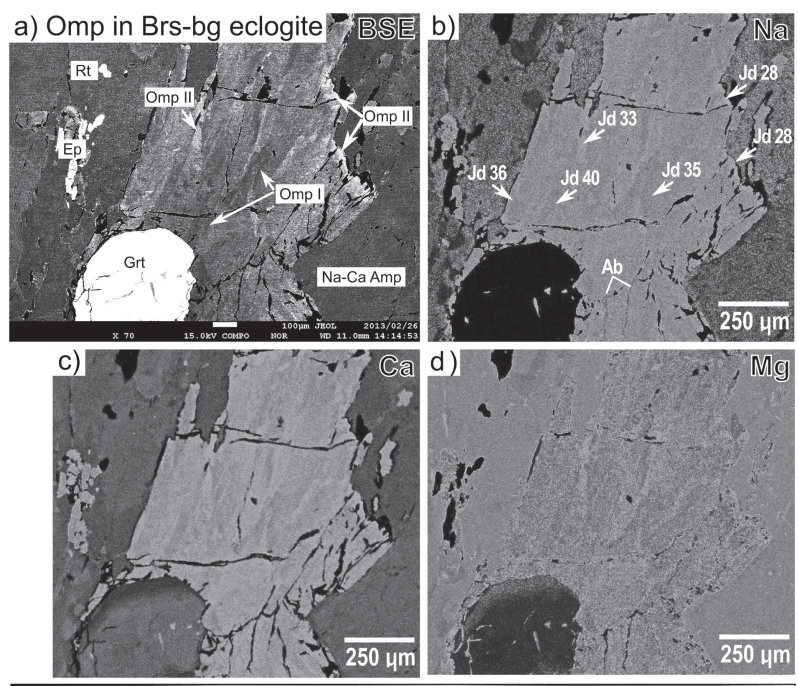

Low

X-ray intensity

High

Figure 8. (a) High contrast back-scattered image of the single grain omphacite in the matrix showing compositional heterogeneity by patchy textures of dark and bright portions, which define matrix I (dark portion) and matrix II (bright portion). Chemical-mapping images of $\mathrm{Na}$ (b), $\mathrm{Ca}$ (c), and $\mathrm{Mg}$ (d) concentrations emphasize that matrix omphacite $\mathrm{I}$ is characterized as $\mathrm{Na}$-rich and $\mathrm{Ca}-$ and $\mathrm{Mg}$-poor, with the opposite characteristics for matrix omphacite II. Color version is available online from http://doi.org/10.2465/jmps. 150907.

ly, omphacite in the barroisite-free eclogite has a higher jadeite component than omphacite in the barroisite-bearing eclogite (Figs. 7a-7c).

All clinopyroxenes in the barroisite-bearing eclogite are also omphacites with slight compositional variations depending on their position (Figs. 7b and 7c). Several clinopyroxene grains included in the core portion of coarse-grained garnet straddle the aegirine-augite and omphacite boundary (Fig. 7b). Omphacite inclusions in the core are characterized by higher acmite and slightly poor jadeite components ( $\left.\operatorname{Aug}_{48-67} \mathrm{Jd}_{19-37} \mathrm{Acm}_{15-22}\right)$ compared to the mantle portion $\left(\mathrm{Aug}_{42-68} \mathrm{Jd}_{18-44} \mathrm{Acm}_{10-19}\right)$ (Fig. 7b). Granoblastic omphacite in the matrix (up to $0.5 \mathrm{~mm}$ in size) of the barroisite eclogite shows a compositional heterogeneity with a patchy texture of dark and bright portions based on the high-contrast of back-scattered electron imaging (Fig. 8a). These dark and bright portions are referred to as the matrix omphacites I and II, respectively. The chemical-mapping images on $\mathrm{Na}, \mathrm{Ca}$, and $\mathrm{Mg}$ emphasized that matrix omphacite I is characterized by an $\mathrm{Na}^{-}$ rich and $\mathrm{Ca}^{-}$and $\mathrm{Mg}$-poor composition and has a compositional range of $\mathrm{Aug}_{47-56} \mathrm{Jd}_{33-44} \mathrm{Acm}_{7-14}$ (Figs. 8a-8d). In contrast, matrix omphacite II is characterized by a relatively $\mathrm{Na}$-poor and $\mathrm{Ca}-$ and $\mathrm{Mg}$-rich composition with a range of Aug ${ }_{54-63} \mathrm{Jd}_{23-33} \mathrm{Acm}_{\text {8-16 }}$ (Figs. 8a-8d). 


\section{White mica}

Representative analyses are listed in Table 2. The line profile of the idioblastic coarse-grained phengite matrix in the barroisite-bearing eclogite $(0.5 \mathrm{~mm}$ wide) (Figs. $9 \mathrm{a}$ and $9 b)$ suggests slightly higher $X_{\mathrm{Si}}[\mathrm{Si} /(\mathrm{Si}+\mathrm{Al})=0.629$ $0.654, \mathrm{Si}=3.45-3.53]$ and $X_{\mathrm{Mg}}\left[\mathrm{Mg} /\left(\mathrm{Mg}+\mathrm{Fe}^{2+}\right)=\right.$ $0.776-0.801]$ in the core compared to the rim portion $\left(X_{\mathrm{Si}}=0.617-0.623, \mathrm{Si}=3.40-3.44, X_{\mathrm{Mg}}=0.763-0.768\right)$ (Figs. 9b and 9c). The $X_{\mathrm{Mg}}$ values along the cleavage of the phengite crystal are $X_{\mathrm{Mg}}=0.733-0.755$ (Fig. 9b). The phengite in contact with secondary chlorite shows similar compositional patterns $\left(X_{\mathrm{Mg}}=0.733-0.740, X_{\mathrm{Si}}=0.615-\right.$ 0.627) (Fig. 9c).

Phengite in the barroisite-free eclogite occurs as an inclusion in the coarse-grained matrix, and fine-grained matrix (Fig. 9c). Phengite inclusions show higher $X_{\mathrm{Si}}$ $\left(X_{\mathrm{Si}}=0.64-0.65, \mathrm{Si}=3.49-3.54, X_{\mathrm{Mg}}=0.70-0.78\right)$ values compared to the matrix phengite (Fig. 9c). In the matrix, coarse-grained phengite $(0.5 \mathrm{~mm}$ wide $)$ shows higher $X_{\mathrm{Si}}$ $\left(X_{\mathrm{Si}}=0.61-0.63, \mathrm{Si}=3.37-3.40, X_{\mathrm{Mg}}=0.67-0.74\right)$ values compared to the fine-grained phengite $(<0.1 \mathrm{~mm}$ wide) $\left(X_{\mathrm{Si}}=0.60-0.61, \mathrm{Si}=3.32-3.39, X_{\mathrm{Mg}}=0.71-0.78\right)$ (Fig. $9 \mathrm{c})$. All of the phengites in the barroisite-free eclogite have similar ranges of $X_{\mathrm{Mg}}$ values (Fig. 9c). Paragonite is rarely observed as an inclusion in the garnet core with $X_{\mathrm{Si}}=0.51$, $X_{\mathrm{Na}}(\mathrm{Na} / \mathrm{Na}+\mathrm{Al})=0.25$, and $\mathrm{Si}=3.04$ (Fig. 4d).

\section{Amphiboles}

Nomenclatures and formulae calculations of amphiboles follow Leake et al. (1997). Representative analyses are listed in Table 2. Analyzed amphiboles in the barroisitebearing eclogite comprise $\mathrm{Na}$ (glaucophane), $\mathrm{Na}-\mathrm{Ca}$ (barroisite and winchite), and $\mathrm{Ca}$ amphiboles (actinolite, tremolite, and magnesio-hornblende) (Fig. 10a; available online from http://doi.org/10.2465/jmps.150907). The amphiboles included in the mantle of coarse-grained garnet (Figs. 3h and 3i) are glaucophanes with composition ranges of $X_{\mathrm{Mg}}\left[\mathrm{Mg} /\left(\mathrm{Mg}+\mathrm{Fe}^{2+}\right)\right]=0.34-0.38,(\mathrm{Na}+$ $\mathrm{K})_{[\mathrm{A}]}=0.22-0.32$, and $\mathrm{Si}=7.78-8.00$, which can be classified as ferroglaucophanes (Leake et al., 1997). Glaucophane as an inclusion in the coarse-grained garnet mantle is commonly in contact with quartz and omphacite (Figs. $3 \mathrm{~h}$ and $3 \mathrm{i}$ ). However, one grain of glaucophane is surrounded by omphacite (Fig. 3i). The glaucophane surrounded by omphacite (glaucophane 1) shows a higher $X_{\mathrm{Mg}}$ composition compared to the glaucophane inclusions in the coarse-grained garnet mantle (glaucophane 2) $\left[X_{\mathrm{Mg}}\right.$ $=0.76,(\mathrm{Na}+\mathrm{K})_{[\mathrm{A}]}=0.26$ and $\left.\mathrm{Si}=7.98\right]$. Ubiquitous nematoblastic amphiboles in the matrix range from sodiccalcic to calcic amphiboles (up to $0.5 \mathrm{~mm}$ in size), which are classified into barroisite, winchite, and magnesiohornblende with the following compositional ranges: $X_{\mathrm{Mg}}=0.77-0.98,(\mathrm{Na}+\mathrm{K})_{[\mathrm{A}]}=0.17-0.53$, and $\mathrm{Si}=$ 7.15-7.66. The dominant amphibole in the matrix is Ca-rich. We observed a barroisite, rimmed by an actinolite/tremolite $\left[X_{\mathrm{Mg}}=0.80-0.96,(\mathrm{Na}+\mathrm{K})_{[\mathrm{A}]}=0.02-0.18\right.$, $\mathrm{Si}=7.64-8.00]$ (Fig. 10a). Glaucophane 3 is locally found as the interstitial phase between the previously mentioned amphiboles (Figs. 3j and 3k), and may texturally coexist with actinolite/tremolite. Glaucophane 3 has a lower $(\mathrm{Na}+\mathrm{K})_{[\mathrm{A}]}(0.01-0.08)$ and narrower range of $X_{\mathrm{Mg}}\left(X_{\mathrm{Mg}}=0.72-0.79, \mathrm{Si}=7.92-8.00\right)$ compared to the inclusion phase (Fig. 10a). Glaucophane was found included in sodic-calcic amphiboles (Figs. $3 \mathrm{j}$ and $3 \mathrm{k}$ ).

All amphiboles in the barroisite-free eclogite, which occur as inclusions in the garnet core and fine-grained matrix grains, are glaucophanes (Fig. 10b). Fine-grained glaucophane in the matrix has higher $X_{\mathrm{Mg}}\left[X_{\mathrm{Mg}}=0.64-\right.$ $\left.0.74,(\mathrm{Na}+\mathrm{K})_{[\mathrm{A}]}=0.00-0.01, \mathrm{Si}=7.98-8.00\right]$ compared to glaucophane inclusions in the garnet core $\left[X_{\mathrm{Mg}}=0.46-\right.$ $\left.0.68,(\mathrm{Na}+\mathrm{K})_{[\mathrm{A}]}=0.05-0.15, \mathrm{Si}=7.92-8.00\right]$ (Fig. 10b).

\section{Other minerals}

Formulae of epidote were calculated by assuming all iron to be $\mathrm{Fe}^{3+}$ and are listed in Table 3 (available online from http://doi.org/10.2465/jmps.150907). In the barroisitebearing eclogite, epidote inclusions in garnet have higher pistacite contents $\left[X_{\mathrm{Fe}}^{3+}=\mathrm{Fe}^{3+} /\left(\mathrm{Fe}^{3+}+\mathrm{Al}\right)=0.20-0.25\right]$ compared to the fine-grained crystals in the matrix $\left[X_{\mathrm{Fe}}^{3+}\right.$ $=0.15-0.16]$. Conversely, in the barroisite-free eclogite, the pistacite content of the epidote inclusions in the garnet core has a wider range $\left[X_{\mathrm{Fe}}^{3+}=0.15-0.33\right]$ than that of the epidote in the matrix $\left[X_{\mathrm{Fe}}^{3+}=0.13-0.18\right]$. Titanite grains are only recognized in the barroisite-bearing eclogite, and they are included in the coarse-grained garnet core (Fig. 3g) in which rutile is absent. They contain $2.61 \mathrm{wt} \% \mathrm{Al}_{2} \mathrm{O}_{3}$ (Table 3). Chlorite is abundant in the barroisite-bearing eclogites. Chlorite inclusions have higher $X_{\mathrm{Fe}}$ contents $\left[X_{\mathrm{Fe}}=\right.$ $\left.\mathrm{Fe}^{2+} /\left(\mathrm{Fe}^{2+}+\mathrm{Mg}\right)=0.65-0.83\right]$ than the other phases. Matrix chlorite in the studied eclogite is coarse-grained, tabular in shape (0.5 mm wide; Fig. $3 \mathrm{c})$, and has a lower $X_{\mathrm{Fe}}$ (0.19-0.26). Secondary chlorite occurs along cracks in the garnet, replacing other minerals, and has $X_{\mathrm{Fe}}=0.27-0.32$ (Figs. 3d and 3f). Chlorites in the barroisite-free eclogite occur as inclusions in the garnet core and as the secondary chlorite filling the garnet cracks. Chlorite inclusions have higher $X_{\mathrm{Fe}}\left(X_{\mathrm{Fe}}=0.75-0.77\right)$ compared to the secondary chlorite $\left(X_{\mathrm{Fe}}=0.35-0.48\right)$. Albite in both eclogites only occurs as an interstitial phase along cracks in the garnet and omphacite with a composition of $X_{\mathrm{Ab}}=0.98-1.00$. 


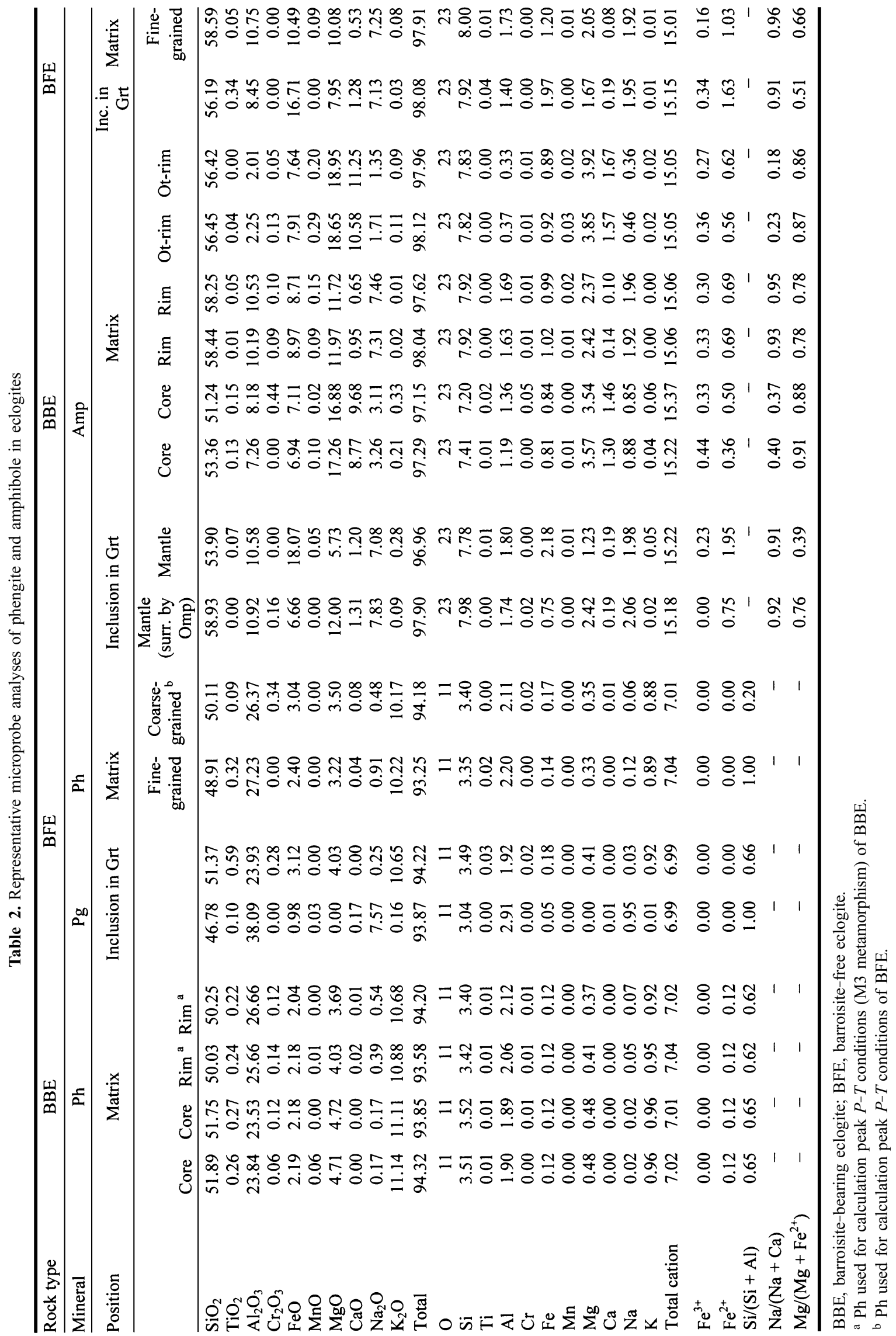



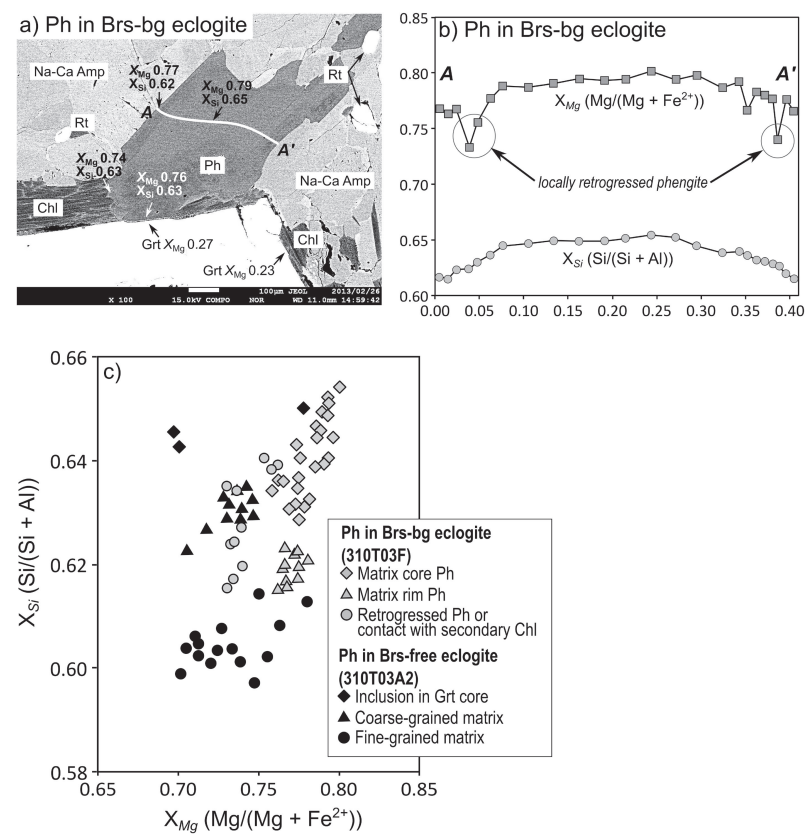

Figure 9. (a) High-contrast back-scattered electron image and microprobe traverse of matrix phengite in the barroisite-bearing eclogite. (b) $X_{\mathrm{Si}}$ and $X_{\mathrm{Mg}}$ components gradually decrease from core to rim. The abruptly decreasing $X_{\mathrm{Mg}}$ components are probably caused by retrogression along cleavage. Chemical characteristics of retrogressed phengite are similar to the rim portion of phengite in contact with secondary chlorite and distinct from matrix phengites (c). Phengite in the barroisite-free eclogite also plot on the $X_{\mathrm{Si}}$ versus $X_{\mathrm{Mg}}(\mathrm{c})$.

\section{DISCUSSION}

Petrography and mineral chemistry analyses reveal that the barroisite-bearing eclogite better preserves the prograde-peak mineral parageneses than the barroisite-free eclogite. Therefore, we estimated the $P-T$ metamorphic evolution of the eclogite from the Bantimala Complex using the barroisite-bearing eclogite 310T03F. Peak $P$ $T$ conditions of the barroisite-free eclogite (310T03A2) were estimated for comparison with the barroisite-bearing eclogite.

\section{Metamorphic evolution}

Based on the textural and mineral chemistry results, the metamorphic evolution of the barroisite-bearing eclogite is divided into four stages, M1 to M4. Each stage can be linked to the zonation of coarse-grained garnet as follows: M1 (garnet core), M2 (garnet mantle), M3 (garnet rim), and M4 (garnet outer-rim). A summary of the mineral assemblages and their chemical characteristics is presented in Figure 11.

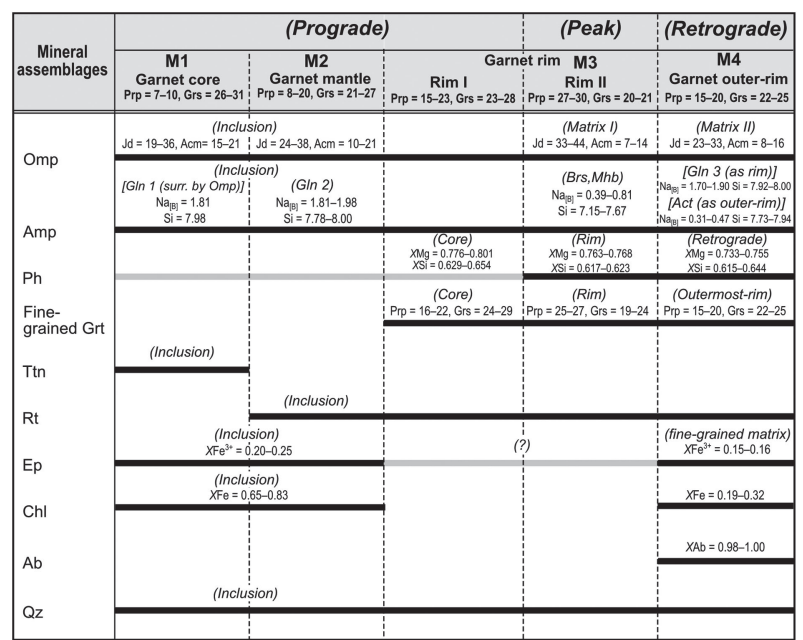

Figure 11. Summary of mineral assemblages and their chemical characteristics in the barroisite-bearing eclogite. The stages correspond to the zonation of coarse-grained garnet. The metamorphic evolution can be divided into four stages, as follows: M1 (garnet core), M2 (garnet mantle), M3 (garnet rim), and M4 (garnet outer-rim) metamorphisms. Grey lines represent phases presumed to be stable.

\section{Prograde stage (M1 and M2).}

The mineral assemblages characteristic of M1 metamorphism are the inclusions in the coarse-grained garnet core. The most representative phases of M1 are omphacite $\left(\mathrm{Jd}_{19-36}\right)$, titanite, epidote $\left(X_{\mathrm{Fe}}^{3+}=0.20-0.25\right)$, and quartz (Figs. $3 \mathrm{~g}$ and 11). Glaucophane was not observed in the garnet core but occurs as inclusions within the garnet mantle (Fig. 3i). Glaucophane 1 surrounded by omphacite shows a higher $X_{\mathrm{Mg}}$ content (up to 0.76) than glaucophane 2 (0.34-0.38). The differences of chemical compositions and the textural relationships with other minerals suggest that glaucophane 1 and 2 were not in equilibrium. The occurrence of glaucophane 1 included in omphacite suggests that glaucophane 1 was formed before omphacite, which was probably in equilibrium with the garnet core during the prograde M1 stage of metamorphism.

The petrogenetic grids from Evans (1990) delineate the disappearance of lawsonite on the lawsonite-blueschist stability field (LBS) by the equilibrium reaction of $\mathrm{Omp}+\mathrm{Lws}=\mathrm{Gln} 1+\mathrm{Ep}+\mathrm{Qz}+\mathrm{H}_{2} \mathrm{O}$ (Fig. 12). Therefore, the absence of prograde lawsonite grains included in the garnet or in other minerals suggests that the prograde reactions took place on the epidote blueschist stability field (EBS) (Fig. 12), which may give the minimum temperature for M1 stage. The experimental studies on natural glaucophane by Maresch (1977) suggested that the maximum stability field of glaucophane at $550{ }^{\circ} \mathrm{C}$ above 
$1.0 \mathrm{GPa}$ (Fig. 12) can be used as the maximum temperature of the M1 stage. The minimum pressure of this stage can be estimated from the jadeite content of omphacite inclusions coexisting with quartz using the equilibrium line from Holland (1983) for the reaction of $\mathrm{Ab}=\mathrm{Jd}$ + Qz. The lowest jadeite content of omphacite inclusions in the coarse-grained garnet core $\left(\mathrm{Jd}_{18}\right)$ might give 0.85 $1.05 \mathrm{GPa}$ as the minimum pressure the M1 stage for an assumed temperature of $350-550{ }^{\circ} \mathrm{C}$ (Fig. 12).

Titanite and epidote grains are included in the coarsegrained garnet core (Fig. 3g). Rutile, which is not observed in the core, appears in the mantle of garnet (Fig. 3h). Manning and Bohlen (1991) calibrated a geobarometry involving titanite, rutile, epidote, and grossular in eclogite based on the dehydration reaction of Ep $+\mathrm{Ttn}=\mathrm{Grs}+\mathrm{Rt}+\mathrm{Qz}+$ $\mathrm{H}_{2} \mathrm{O}$. Garnet in the studied sample does not show an increase in grossular from the core to the mantle. However, the amount of grossularic garnet along a $P-T$ path also depends on the relative enrichment/depletion of the other garnet end-members (i.e., pyrope, almandine, and spessartine) as a result of net-transfer reactions, except for the one considered by Manning and Bohlen (1991). Therefore, we used this barometer to estimate the $P$ conditions of the equilibrium of titanite, epidote, and grossular in the coarse-grained garnet core only. The activity of the grossular component in the garnet core was calculated from the mixing model of Berman (1990). The titanite, clinozoisite/ epidote, rutile, quartz, and $\mathrm{H}_{2} \mathrm{O}$ activities were calculated following Manning and Bohlen (1991). The activity of titanite (Table 3) was calculated as $X_{C a} X_{T i} X_{S i}\left[X_{O}\right]^{5}$ with $X_{O}=\left(5-X_{A l}-X_{F e}^{3+}\right) / 5$ by assuming the $\mathrm{F}$ and $\mathrm{OH}$ substitutions were balanced by $\mathrm{Al}$ and $\mathrm{Fe}^{3+}$, which correspond to $a_{T t n}=0.807$. The activity of clinozoisite/epidote was calculated as $X_{C a}^{2} X_{A l}^{2}\left(1-\mathrm{Fe}^{3+}\right) X_{S i}^{3}$ with the maximum pistacite selected (Table 3 ) to give the maximum pressure, which corresponds to $a_{C z o}=0.349$. Activities of rutile, quartz, and $\mathrm{H}_{2} \mathrm{O}$ were assumed to be 1 (Manning and Bohlen, 1991). For this equilibrium, we obtained a pressure of 1.65-1.45 GPa for the assumed temperature of 350-550 ${ }^{\circ} \mathrm{C}$, which is interpreted as the maximum $P$ of the M1 stage (Fig. 12). Based on the $P-T$ estimations, it may be concluded that the $P-T$ conditions of M1 stage are $0.9-1.5$ $\mathrm{GPa}$ at $350-550{ }^{\circ} \mathrm{C}$ (Fig. 12).

The M2 metamorphism is characterized by inclusions of glaucophane $2\left(\mathrm{Na}_{[\mathrm{B}]}=1.81-1.98, \mathrm{Si}=7.78-\right.$ $8.00)$, epidote $\left(X_{\mathrm{Fe}}^{3+}=0.20-0.25\right)$, omphacite $\left(\mathrm{Jd}_{24-38}\right)$, quartz, and rutile in the coarse-grained garnet mantle. Epidote inclusions are less common in the mantle portion. Moreover, glaucophane 2 is observed in contact with quartz (Figs. $3 \mathrm{~h}$ and 3i), and several grains are included in the omphacite (Fig. 3i). Hence, at the end of this stage, glaucophane and epidote were consumed to

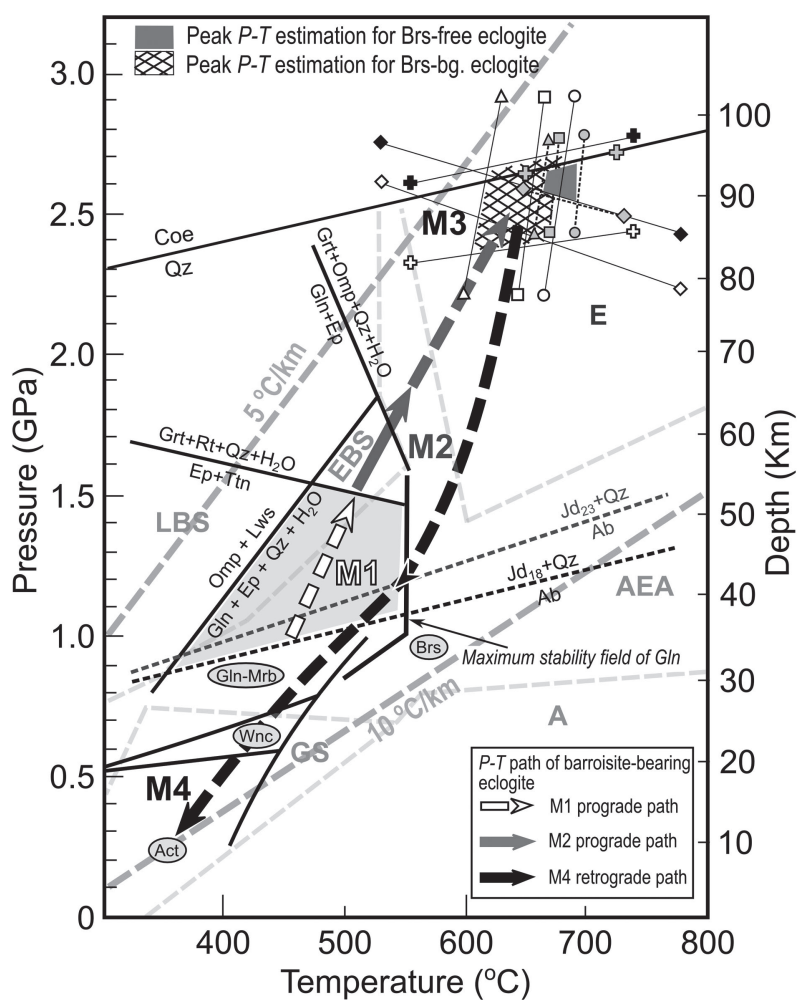

Figure 12. $P-T$ diagram for prograde, peak, and retrograde metamorphism of eclogites from the Bantimala Complex. The facies boundaries are from Evans (1990): LBS, lawsonite blueschistfacies; E, eclogite-facies; AEA, albite epidote amphibolite-facies; A, amphibolite-facies; GS, greenschist-facies. Experimentally determined reactions: (1) $\mathrm{Ab}=\mathrm{Jd}+\mathrm{Qz}$ (Holland, 1983); (2) $\mathrm{Ep}+\mathrm{Ttn}=\mathrm{Grt}+\mathrm{Rt}+\mathrm{Qz}+\mathrm{H}_{2} \mathrm{O}$ (Manning and Bohlen, 1991); (3) Gln $+\mathrm{Ep}=\mathrm{Grt}+\mathrm{Omp}+\mathrm{Qz}+\mathrm{H}_{2} \mathrm{O}$ (Evans, 1990); (4) coesite and quartz stability field (Hemingway et al., 1998); (5) maximum stability field of glaucophane (Maresch, 1977); (6) amphibole solid-solution (Otsuki and Banno, 1990). Garnet-clinopyroxene geothermometry symbols: circle from Ellis and Green (1979), square from Powell (1985), and triangle from Ravna (2000). White-filled symbols refer to estimates for the barroisite-bearing eclogite, whereas small gray-filled symbols are estimates for the barroisite-free eclogite. Garnet-clinopyroxene-phengite geobarometry symbols: diamond and plus from Carswell et al. (1997) and Ravna and Terry (2004), respectively. White black-filled symbols refer to minimum and maximum values of $\mathrm{Si}$ contents in phengite, respectively, from the barroisite-bearing eclogite. Gray-filled symbols are the estimated peak pressure ranges from the barroisite-free eclogite.

form the coarse-grained garnet mantle and omphacite following the reaction proposed by Evans (1990):

$$
\mathrm{Gln} 2+\mathrm{Ep}=\mathrm{Grt}+\mathrm{Omp}+\mathrm{Qz}+\mathrm{H}_{2} \mathrm{O},
$$

which indicates that the blueschist/eclogite-facies transition lies near $1.9 \mathrm{GPa}$ at $525^{\circ} \mathrm{C}$ and $1.6 \mathrm{GPa}$ at $550^{\circ} \mathrm{C}$ (Fig. 12). This marks the later stages of the M2 metamorphism (Fig. 12). 


\section{Peak stage (M3)}

The M3 metamorphism corresponds to the peak metamorphic stage. Textural relations suggest that the peak eclogite-facies condition is displayed by the equilibrium of garnet rim II $\left(\mathrm{Alm}_{48-50} \mathrm{Sps}_{2-3} \operatorname{Prp}_{27-30} \mathrm{Grs}_{20-21}\right)$, matrix omphacite I ( $\left.\operatorname{Aug}_{47-56} \mathrm{Jd}_{33-44} \mathrm{Acm}_{7-14}\right)$, sodic-calcic amphibole, phengite rim $\left(X_{\mathrm{Si}}=0.617-0.623, X_{\mathrm{Mg}}=0.763-\right.$ 0.768 ), rutile, and quartz (Fig. 11). The compositionally patchy texture of matrix omphacite is interpreted as a result of dissolution-precipitation processes by fluid infiltration (Putnis and John, 2010). The omphacites with higher jadeite contents (omphacite I) were replaced by fluid infiltration to form the omphacites with lower jadeite contents (omphacite II), which are likely in the retrogression metamorphism stage. Furthermore, the omphacites with a lower jadeite content (omphacite II), represented by bright portions of back-scattered image, not only have a parallel orientation to the c axis of omphacites but also have an orientation that follows the rim portion of omphacite (Fig. 8a). Hence, this provides strong evidence that matrix omphacite I is in equilibrium at the peak $P-T$ condition.

Mineral chemistry and chemical-mapping analyses suggest that the fine-grained garnet was formed during the same stage as growth of the rim portion of the coarse-grained garnet during the peak metamorphic stage.

The peak temperature is determined using the $\mathrm{Fe}^{2+}-$ $\mathrm{Mg}$ exchange equilibrium in the garnet-clinopyroxene pair. The highest pyrope $\left(\operatorname{Prp}_{29}\right)$ and jadeite $\left(\mathrm{Jd}_{44}\right)$ contents of the garnet rim II and matrix omphacite I (Table 1), respectively, were selected to estimate the maximum temperature for this eclogite. The geothermometries from Ellis and Green (1979), Powell (1985), and Ravna (2000) gave temperatures of $606-667{ }^{\circ} \mathrm{C}$ for an assumed pressure of $2.5 \mathrm{GPa}$ (Fig. 12).

The barometries proposed by Carswell et al. (1997) and Ravna and Terry (2004) were used to calculate the $P$ condition. The peak pressure and temperature were determined using the pyrope +2 grossular +3 celadonite $=6$ diopside +3 muscovite equilibrium in the coexisting garnet, omphacite, and phengite assemblages. The pairs of garnet rim II and matrix omphacite I applied for the thermometry above were also used for this barometry. Petrographical observation shows that the rim portion of the idioblastic coarse-grained phengite is in equilibrium with garnet rim II, which has the highest pyrope composition $\left(\operatorname{Prp}_{29}\right)$, and with omphacite I (Figs. 3e and 3f). Hence, this evidence suggests that this portion is in equilibrium at the peak condition. Coarse-grained tabular phengite in the matrix has a higher $X_{\mathrm{Si}}$ component in the core $\left(X_{\mathrm{Si}}=\right.$ $0.629-0.654)$ than in $\operatorname{rim}\left(X_{\mathrm{Si}}=0.617-0.623\right)$ (Figs. 9a- 9c). It is problematic to select an appropriate composition for phengite at the peak pressure condition. Generally in eclogites, phengites with higher Si contents yield maximum pressures (e.g., Nowlan et al., 2000; Tsujimori et al., 2006a). However, petrographical relations shown by the direct contact of the rim portion of coarse-grained phengite with garnet rim II do not reflect any $\mathrm{Si}-\mathrm{Al}$ exchange between the two minerals (Figs. 3e and 9a), suggesting that the rim portion of coarse-grained phengite is in equilibrium with the garnet rim II and matrix omphacite I as the peak assemblage in this eclogite. The lowest and highest $\mathrm{Si}$ contents in the phengite rim ( $\mathrm{Si}=3.40$ 3.44 ) are used to set the minimum and maximum pressures in this stage (Table 2). The results give a range of 2.3-2.7 GPa at $600-680{ }^{\circ} \mathrm{C}$, which plots around the coesite-quartz transition line (Hemingway et al., 1998; Fig. 12). This is consistent with no evidence of coesite or its pseudomorph in this rock.

The peak $P-T$ conditions of the barroisite-free eclogite are estimated using the same methods as those used for the barroisite-bearing eclogite. The garnet, omphacite, phengite, and quartz were stable at the peak conditions of this rock. The highest pyrope $\left(\operatorname{Prp}_{20}\right)$ of the garnet rim, jadeite $\left(\mathrm{Jd}_{46}\right)$ of omphacite, and $\mathrm{Si}(\mathrm{Si}=3.40)$ of coarse-grained phengite in the matrix (Tables 1 and 2) were selected to set the maximum $T$ and $P$ for the barroisite-free eclogite. The results give narrow ranges of $P$ and $T, 2.5-2.7 \mathrm{GPa}$ at $650-690^{\circ} \mathrm{C}$, which are slightly higher than the estimated peak $P-T$ condition of the barroisitebearing eclogite (Fig. 12). The estimated $P-T$ conditions of both eclogites exhibit slightly higher pressures and temperatures $\left(\sim 0.3 \mathrm{GPa}\right.$ and $\sim 50^{\circ} \mathrm{C}$ are higher for maximum value range of $P$ and $T$, respectively) compared to previous results from Miyazaki et al. (1996) (1.8-2.4 GPa at $\left.580-640{ }^{\circ} \mathrm{C}\right)$. However, Parkinson et al. (1998), and Parkinson and Katayama (1999) reported evidence of ultrahigh-pressure metamorphism in the Bantimala Complex from the radial-cracks and polymorph texture interpreted as a quartz pseudomorph after coesite in the jadeite-garnet-quartz rock and coesite inclusions in the zircon grains from quartzite. This feature corroborates the possibility of slightly higher $P-T$ conditions relative to the estimates of Miyazaki et al. (1996), possibly up to ultrahigh-pressure conditions before decompression to the estimated peak $P-T$ condition.

\section{Retrograde stage (M4)}

The retrograde M4 metamorphism is represented by the mineral assemblages of the garnet outer-rim (Alm $47-55$ $\left.\mathrm{Sps}_{4-6} \operatorname{Prp}_{15-20} \mathrm{Grs}_{22-25}\right)$, glaucophane $3\left(\mathrm{Na}_{[\mathrm{B}]}=1.70-\right.$ $1.90, \mathrm{Si}=7.92-8.00$ ), fine-grained epidote, chlorite, phen- 
gite, and actinolite. The jadeite-poor portions within granoblastic omphacite in the matrix were also probably created by retrograde decompression during exhumation (Figs. 8a-8d). The equilibrium line for the reaction of jadeite + quartz $=$ albite using the model by Holland (1983) was used to estimate the $P$ condition for the retrograde omphacite. The lowest jadeite composition of matrix omphacite II $\left(\mathrm{Jd}_{23}\right)$ (Table 1) is used and gives a pressure of 1.1-1.3 GPa for an assumed temperature of 500$600{ }^{\circ} \mathrm{C}$ (Fig. 12). The range of assumed temperature follows the maximum stability field of glaucophane $\left(550^{\circ} \mathrm{C}\right)$ proposed by Maresch (1977), which has maximum stability field of glaucophane at temperature $550^{\circ} \mathrm{C}$ above 1.0 $\mathrm{GPa}$, as explained in the prograde stage section. The result provides the maximum stability field of omphacite during the retrograde decompression stage.

The decreasing $X_{\mathrm{Mg}}$ values along the cleavage of the phengite crystal $\left(X_{\mathrm{Mg}}=0.733-0.755\right)$ (Fig. $\left.9 \mathrm{~b}\right)$ probably occur because of local retrogression along cleavage of the crystal. This is confirmed by the chemical composition of phengite in contact with secondary chlorite, which shows similar compositional patterns $\left(X_{\mathrm{Mg}}=0.733-0.740, X_{\mathrm{Si}}=\right.$ 0.615-0.627) (Fig. 9c).

Textural relationships among amphiboles in the matrix indicate that sodic-calcic amphiboles are partly rimmed by a thin layer of glaucophane (Figs. $3 \mathrm{j}$ and $3 \mathrm{k}$ ). This suggests that the early stage of retrograde metamorphism was in the glaucophane-stability field. Based on the experimental studies on natural glaucophane by Maresch (1977), the occurrence of glaucophane 3 suggests that the retrograde $P-T$ path should have passed through the stability field of glaucophane (Fig. 12).

Sodic-calcic amphibole and glaucophane 3 were finally rimmed by actinolite (Fig. $3 \mathrm{j}$ and $3 \mathrm{k}$ ). The following continuous reaction probably took place (Maruyama et al., 1996)

$$
\mathrm{Gln}+\mathrm{Ep}+\mathrm{Qz}+\mathrm{H}_{2} \mathrm{O}=\mathrm{Act}+\mathrm{Ab}+\mathrm{Chl} .
$$

This reaction took place in greenschist-facies conditions (Fig. 12).

The retrograde path can be depicted in the solid-solution diagram for amphibole from Otsuki and Banno (1990) as a qualitatively expected retrograde $P-T$ path (Fig. 12). However, this diagram and the hydration reaction of $\mathrm{Brs}+\mathrm{Hem}+\mathrm{H}_{2} \mathrm{O}=\mathrm{Gln}-\mathrm{Mrb}+\mathrm{Ep}+\mathrm{Chl}+\mathrm{Ab}+$ Qz were originally proposed to explain the prograde stage of hematite-bearing basic schists from the Sanbagawa metamorphic belt (Otsuki and Banno, 1990). Our mineral assemblages and textures in the retrograde stage may also use this reaction. Therefore, the hydration reaction and the solid-solution diagram of amphibole might explain the retrograde stage of eclogite from the Bantimala Complex in the same way as other researchers used it to explain the retrograde stage of eclogite (e.g., Bantimala Complex: Miyazaki et al., 1996; Sanbagawa belt: Matsumoto et al., 2003).

\section{Tectonic implications}

The Bantimala Complex is considered to be a Pacific-type metamorphic belt (Ernst, 2006) that includes ophiolitic serpentinites, MORB and seamount fragments, bedded cherts, and trench turbidites. The estimated peak $P-T$ conditions are $\sim 0.3 \mathrm{GPa}$ and $\sim 50^{\circ} \mathrm{C}$ higher than the maximum value ranges of estimated $P-T$ conditions from a previous study (Miyazaki et al., 1996). The prograde $P-T$ path shows a very low geothermal gradient of $\sim 5^{\circ} \mathrm{C} / \mathrm{km}$.

The retrograde $P-T$ path until the M4 stage $(<0.5$ $\mathrm{GPa}$ at $<350{ }^{\circ} \mathrm{C}$ ) (Fig. 12) is consistent with previous work (Miyazaki et al., 1996). The metamorphic evolutions from the prograde to retrograde stages show a very narrow open clockwise $P-T$ path or nearly retrace the prograde trajectory with a low geothermal gradient $\left(\sim 7.5^{\circ} \mathrm{C} /\right.$ $\mathrm{km})$ (Fig. 12). The proximate retracing of the prograde trajectory by the early retrograde stage may be explained by the exhumation processes, which is a migrated backup of the thin slices of the high-pressure complex in the subduction zone. The exhumation is also relatively parallel to the subducting plate, which is a response to isostatic forces during a continued oceanic plate descent (Ernst, 1988; Maruyama et al. 1996; Ernst et al., 1997).

The eclogites in the Bantimala Complex are enclosed in sheared serpentinite and intercalated with mélange units (Sukamto, 1982; Miyazaki et al., 1996). Platt (1993) pointed out that buoyancy is the only effective force for exhuming rocks from deeply subducted levels to the base of the crust. The serpentinites are extremely buoyant with respect to the oceanic crust that mainly consists of mafic rocks that have been transformed to eclogites during subduction, increasing their density so that they are denser than average mantle rocks (Hermann et al., 2000). Our $P-T$ estimates $\left(2.3-2.7 \mathrm{GPa}\right.$ at $615-680^{\circ} \mathrm{C}$ for barroisite-bearing and $2.5-2.7 \mathrm{GPa}$ at $650-690^{\circ} \mathrm{C}$ for barroisite-free eclogites) fit the stability field of antigorite along subduction zone gradients, i.e. $\sim 650^{\circ} \mathrm{C}$ at $2.7 \mathrm{GPa}$ (Wunder and Schreyer, 1997; Agard et al., 2009). Thus, serpentinites may have enhanced exhumation of HP rocks in the Bantimala Complex (Hermann et al., 2000; Ernst, 2010). Furthermore, the presence of mélange units intercalated with high-pressure metamorphic rocks and the chaotic occurrence of different metamorphic facies (e.g., eclogite, blueschist, greenschist) (Sukamto, 1982) has been proposed for a subduction channel environment 
(Gerya et al., 2002; Federico et al., 2007).

Some authors considered that the Bantimala and Luk Ulo Complexes may have constituted a single subduction complex (Hamilton, 1979; Parkinson et al., 1998; Kadarusman et al., 2007). This was deduced from the common occurrence of high-pressure metamorphic rocks, an accretionary complex, mélange unit, serpentinite in the two complexes, along with relatively similar ranges of Cretaceous K-Ar ages [113-137 Ma for Bantimala Complex (Wakita et al., 1994, 1996; Parkinson et al., 1998); 110-124 Ma for Luk Ulo Complex (Ketner et al., 1976; Miyazaki et al., 1998; Parkinson et al., 1998)].

In contrast with the Bantimala Complex, pelitic schists are more dominant, and eclogite-facies rocks are rarely found in the Luk Ulo Complex. The high-pressure metamorphic rocks from the Luk Ulo Complex show lower pressures and temperatures than the Bantimala Complex. Miyazaki et al. (1998) estimated the peak condition of jadeite-garnet-quartz-glaucophane rock as $2.2 \pm 0.2$ $\mathrm{GPa}$ at $530 \pm 40{ }^{\circ} \mathrm{C}$ (Fig. 13). Kadarusman et al. (2007) reported that the eclogites from the Luk Ulo Complex were metamorphosed under very low-temperature conditions $\left(365-410{ }^{\circ} \mathrm{C}\right.$ at $\left.2.0-2.3 \mathrm{GPa}\right)$ with a low geothermal gradient $\left(\sim 6^{\circ} \mathrm{C} / \mathrm{km}\right)$ and proposed counter-clockwise and clockwise $P-T$ paths for tourmaline eclogite and barroisite-free eclogite, respectively (Fig. 13). During subduction, some of the rock moved away from the boundary of overlying hot mantle, which produced cooling at increasing depths. Later the subduction-channel tectonically mixed the eclogites with clockwise and counter-clockwise $P-T$ paths (Kadarusman et al., 2007). The estimated $P-T$ paths of the eclogites from the Luk Ulo Complex (Kadarusman et al., 2007) and Bantimala Complex (Miyazaki et al., 1996; this study) have a difference in peak temperature of $\pm 250{ }^{\circ} \mathrm{C}$ (Fig. 13). The counterclockwise $P-T$ path of eclogites in the Luk Ulo Complex (Kadarusman et al., 2007) has been not yet reported for the Bantimala Complex.

Both of the complexes have a low geothermal gradient $\left[\sim 7.5{ }^{\circ} \mathrm{C} / \mathrm{km}\right.$ for the Bantimala Complex (this study); $\sim 6{ }^{\circ} \mathrm{C} / \mathrm{km}$ for Luk Ulo Complex (Kadarusman et al., 2007)], which can be attained only by the subduction of old and cold oceanic crust with its lithosphere, and the rate of shear-heating should be low (Peacock, 1996; Tsujimori et al., 2006b). In subduction zones, the temperature at depth may vary according to variations in the convergence rate, thermal structure (age and sediment thickness) of the incoming lithosphere, rates of shear heating (Peacock, 1996), and heat flow from the mantle wedge. The above differences of the temperature at depth in the subduction zone and similar low geothermal gradients in the Bantimala and Luk Ulo Complexes can be

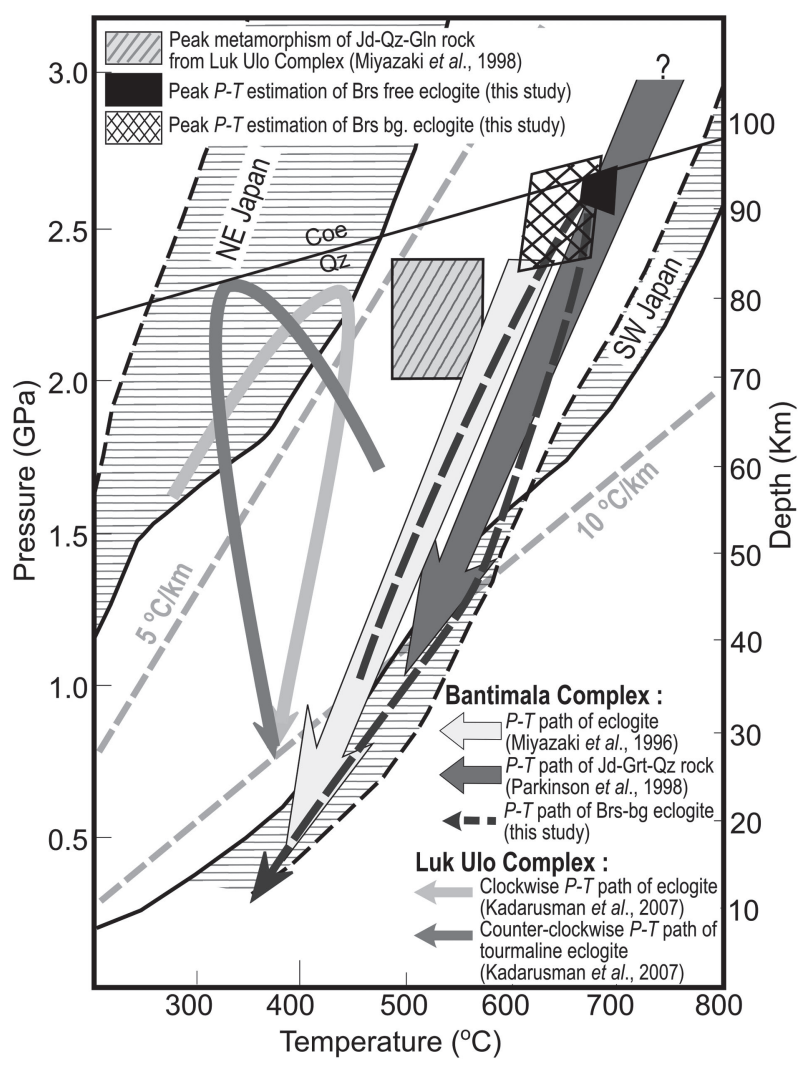

Figure 13. Compiled $P-T$ conditions of high-pressure metamorphic rocks from the Bantimala and Luk Ulo Complexes. Hatched areas represent the inferred $P-T$ conditions for the oceanic crust beneath present-day NE Japan (cold) and SW Japan (warm) subduction zones (Peacock and Wang, 1999).

explained by warm and cool subduction metamorphism, respectively, as proposed by Peacock and Wang (1999). Peacock and Wang (1999) proposed the model of warm and cool subduction metamorphism using examples from SW and NE Japan (Fig. 10). In the relatively warm subduction zone of SW Japan, subducted oceanic crust passes through the greenschist-facies, and the transformation to eclogite may occur at a depth of $\sim 50 \mathrm{~km}$. In contrast, relatively cool subduction zones like NE Japan pass through the blueschist-facies and eclogite may not form until a depth of $>100 \mathrm{~km}$. On the other hand, the cool subduction zone might result in very low-temperature eclogite-facies metamorphism. Transferring this situation to the Cretaceous subduction in central Indonesia, the differences of temperature at depth in the subduction zones suggest that subduction environments beneath the Bantimala Complex might possibly be warmer than beneath the Luk Ulo Complex (Fig. 13).

At the present stage, only $\mathrm{K}-\mathrm{Ar}$ ages interpreted as the timing of exhumation were recognized in these complexes, which show similar ranges for the Luk Ulo (110124 Ma: Ketner et al., 1976; Miyazaki et al., 1998; Par- 
kinson et al., 1998) and Bantimala Complexes (113-137 Ma: Wakita et al., 1994, 1996; Parkinson et al., 1998). As a consequence, there are two possibilities for the subduction system in these complexes: (1) the Bantimala and Luk Ulo Complexes might be derived from different subduction complexes, similar to the NE and SW Japan subduction system, or (2) the Bantimala and Luk Ulo Complexes are derived from a single subduction system, as proposed by Hamilton (1979), Parkinson et al. (1998), and Kadarusman et al. (2007), and experienced metamorphic evolution as a result of increasing/decreasing geothermal gradients during continuous subduction. In order to understand the detailed tectonic conditions of these two complexes, the metamorphic ages of both complexes and their $P-T-t$ evolutions should be investigated. The present results, however, are definitely a step in that direction.

\section{ACKNOWLEDGMENTS}

We would like to thank to the staff of Geological Engineering Hasanuddin University, Geological Engineering Gadjah Mada University, and Indonesian Institute of Science (LIPI) Karangsambung for their assistance during the field survey in Indonesia and for their valuable discussions. We also acknowledge Dr. Sajeev Krishnan and Dr. Alberto Vitale who gave valuable suggestions and comments for this manuscript. An early version of this manuscript was submitted to the Journal of Asian Earth Sciences; we appreciate the constructive reviews from Prof. Emeritus J.G. Liou, Dr. Sarah Roeske, and the anonymous reviewers. Fieldwork was also supported by Grants-in-Aid for Scientific Research (No. 21253008 and 22244063 to Y. Osanai) from the Ministry of Education, Culture, Sports, Science and Technology, Japan.

\section{SUPPLEMENTARY MATERIAL}

Figures 2, 6, 7, 10, Table 3, and color version of Figures $3,4,5$, and 8 are available online from http://doi.org/ $10.2465 / \mathrm{jmps} .150907$.

\section{REFERENCES}

Agard, P., Yamato, P., Jolivet, L. and Burov, E. (2009) Exhumation of oceanic blueschists and eclogites in subduction zones: Timing and mechanisms. Earth-Science Reviews, 92, 53-79.

Berman, R.G. (1990) Mixing properties of Ca-Mg-Fe-Mn garnets. American Mineralogist, 75, 328-344.

Carswell, D.A., O'brien, P.J., Wilson, R.N. and Zhai, M. (1997) Thermobarometry of phengite-bearing eclogites in the Dabie Mountains of central China. Journal of Metamorphic Geology, $15,239-252$.

Cheng, H., Nakamura, E., Kobayashi, K. and Zhou, Z. (2007) Ori- gin of atoll garnets in eclogites and implications for the redistribution of trace elements during slab exhumation in a continental subduction zone. American Mineralogist, 92, 11191129.

Droop, G.T.R. (1987) A general equation for estimating $\mathrm{Fe}^{3+}$ concentrations in ferromagnesian silicates and oxides from microprobe analyses, using stoichiometric criteria. Mineralogical Magazine, 51, 431-435.

Ellis, D.J. and Green, D.H. (1979) An experimental study of the Effect of $\mathrm{Ca}$ upon garnet-clinopyroxene $\mathrm{Fe}-\mathrm{Mg}$ exchange equilibria. Contributions to Mineralogy and Petrology, 71, $13-22$.

Ernst, W.G. (1988) Tectonic history of subduction zones from retrograde blueschist $P-T$ path. Geology, 16, 1081-1084.

Ernst, W.G. (2006) Preservation/exhumation of ultrahigh-pressure subduction complexes. Lithos, 92, 321-335.

Ernst, W.G. (2010) Subduction-zone metamorphism, calc-alkaline magmatism, and convergent-margin crustal evolution. Gondwana Research, 18, 8-16.

Ernst, W.G., Maruyama, S. and Wallis, S. (1997) Buoyancy-driven, rapid exhumation of ultrahigh-pressure metamorphosed continental crust. National Academy of Science Proceedings, 94, 9532-9537.

Evans, B.W. (1990) Phase relations of epidote-blueshists. Lithos, $25,3-23$.

Federico, L., Crispini, L., Scambelluri, M. and Capponi, G. (2007) Ophiolite mélange zone records exhumation in a fossil subduction channel. Geology, 35, 499-502.

Gerya, T.V., Stöckhert, B. and Perchuk, A.L. (2002) Exhumation of high-pressure metamorphic rocks in a subduction channel: A numerical simulation. Tectonics, 21, 1-15.

Hamilton, W. (1979) Tectonics of the Indonesia region. pp. 345, U.S. Geological Survey Professional Paper, 1078.

Hemingway, B.S., Bohlen, S.R., Hankins, W.B., Westrum Jr, E.F. and Kuskov, O.L. (1998) Heat capacity and thermodynamic properties for coesite and jadeite, reexamination of quartz-coesite equilibrium boundary. American Mineralogist, 83, 409418.

Hermann, J., Müntener, O. and Scambelluri, M. (2000) The importance of serpentinite mylonites for subduction and exhumation of oceanic crust. Tectonophysics, 327, 225-238.

Holland, T.J.B. (1983) The experimental determination of activities in disordered and short-range ordered jadeitic pyroxenes. Contributions to Mineralogy and Petrology, 82, 214-220.

Kadarusman, A. and Parkinson, C.D. (2000) Petrology and P-T evolution of garnet peridotites from central Sulawesi, Indonesia. Journal of Metamorphic Geology, 18, 193-209.

Kadarusman, A., Massonne, H.J., Roermund, V.H., Permana, H. and Munasri (2007) P-T evolution of eclogites and blueschists from the Luk Ulo Complex of Central Java, Indonesia. International Geology Review, 49, 329-356.

Ketner, K.B., Kastowo, S., Modjo, C.W., Naeser, H.D., Obradovich, K., Robinson, T., Suptandar and Wikarno (1976) PreEocene rocks of Java, Indonesia. Journal of Research, United States Geological Survey, 4, 605-614.

Lanzirotti, A. (1995) Yttrium zoning in metamorphic garnets. Geochemica et Cosmochimica Acta, 59, 4105-4110.

Leake, B.E., Woolley, A.R., Arps, C.E.S., Birch, W.D., Gilbert, M.C., Grice, J.D., Hawthorne, F.C., Kato, A., Kisch, H.J., Krivovichev, V.G., Linthout, K., Laird, J., Mandarino, J.A., Maresch, W.V., Nickel, E.H., Rock, N.M.S., Schumacher, J.C., Smith, D.C., Stephenson, N.C.N., Ungaretti, L., Whit- 
taker, E.J.W. and Youzhi, G. (1997) Nomenclature of amphiboles: report of the subcommittee on amphiboles of the International Mineralogical Association, Commission on New Minerals and Mineral Names. The Canadian Mineralogist, $35,219-246$.

Manning, C.E. and Bohlen, S.R. (1991) The reaction titanite + kyanite $=$ anorthite + rutile and titanite-rutile barometry in eclogites. Contributions to Mineralogy and Petrology, 109, 1-9.

Maresch, W.V. (1977) Experimental studies on glaucophane: an analysis of present knowledge. Tectonophysics, 43, 109-125.

Maruyama, S., Liou, J.G. and Terabayashi, M. (1996) Blueschists and eclogites of the world and their exhumation. International Geology Review, 38, 485-594.

Matsumoto, M., Wallis, S., Aoya, M., Enami, M., Kawano, J. and Seto, Y. (2003) Petrological constraints on the formation conditions and retrograde $\mathrm{P}-\mathrm{T}$ path of the Kotsu eclogite unit, central Shikoku. Journal of Metamorphic Geology, 21, 363376.

Miyazaki, K., Zulkarnain, I., Sopaheluwakan, J. and Wakita, K. (1996) Pressure-temperature conditions and retrograde paths of eclogites, garnet-glaucophane rocks and schists from South Sulawesi, Indonesia. Journal of Metamorphic Geology, 14, 549-563.

Miyazaki, K., Sopaheluwakan, J., Zulkarnain, I. and Wakita, K. (1998) Jadeite-quartz-glaucophane rock from Karangsambung, Central java, Indonesia and its tectonic implications. The Island Arc, 7, 223-230.

Nowlan, E.U., Schertl, H.-P. and Schreyer (2000) Garnet-omphacite-phengite thermobarometry of eclogites from the coesitebearing unit of the southern Dora-Maira Massif, Western Alps. Lithos, 52, 197-214.

Okamoto, K., Liou, J.G. and Ogasawara, Y. (2000) Petrology of the diamond-grade eclogite in the Kokchetav Massif, northern Kazakhstan. The Island Arc, 9, 379-399.

Otsuki, M. and Banno, S. (1990) Prograde and retrograde metamorphism of hematite-bearing basic schists in the Sanbagawa belt in central Shikoku. Journal of Metamorphic Geology, 8, 425-439.

Parkinson, C.D. (1998) An outline of the petrology, structure, and age of the Pompangeo schist Complex of central Sulawesi, Indonesia. The Island Arc, 7, 231-245.

Parkinson, C.D., Miyazaki, K., Wakita, K., Barber, A.J. and Carswell, A. (1998) An overview and tectonic synthesis of the pre-Tertiary very-high-pressure metamorphic and associated rocks of Java, Sulawesi and Kalimantan, Indonesia. The Island Arc, 7, 184-200.

Parkinson, C.D. and Katayama, I. (1999) Present-day ultrahighpressure conditions of coesite inclusions in zircon and garnet: evidence from laser Raman microspectroscopy. Geology, 27, 979-982.

Peacock, S.M. (1996) Thermal and petrologic structure of subduction zones, In Subduction: Top to Bottom (Bebout, G.E., Scholl, D., Kirby, S. and Platt, J. Eds.). AGU Geophysical
Monograph, 96, 119-133.

Peacock, S.M. and Wang, K. (1999) Seismic consequences of warm versus cool subduction zone metamorphism: Examples from northeast and southwest Japan. Science, 286, 937-939.

Platt, J.P. (1993) Exhumation of high pressure rocks: A review of concepts and processes. Terra Nova, 5, 119-133.

Powell, R. (1985) Regression diagnostics and robust regression in geothermometer/geobarometer calibration: the garnet-clinopyroxene geothermometer revisited. Journal of Metamorphic Geology, 3, 231-243.

Putnis, A. and John, T. (2010) Replacement processes in the earth's crust. Elements, 6, 159-164.

Ravna, K.E. (2000) The garnet-clinopyroxene $\mathrm{Fe}^{2+}-\mathrm{Mg}$ geothermometer: an updated calibration. Journal of Metamorphic Geology, 18, 211-219.

Ravna, K.E.J. and Terry, M.P. (2004) Geothermobarometry of UHP and HP eclogites and schists - an evaluation of equilibria among garnet-clinopyroxene-kyanite-phengite-coesite/ quartz. Journal of Metamorphic Geology, 22, 579-592.

Ryburn, R.J., Raheim, A. and Green, D.H. (1976) Determination of the $\mathrm{P}, \mathrm{T}$ paths of natural eclogites during metamorphism-record of subduction. Lithos, 9, 161-164.

Sukamto, R. (1982) Geological map of Pangkajene and western part of Watampone Quadrangles, Sulawesi. Scale 1:250,000. Geological Research and Development Centre of Indonesia.

Tsujimori, T., Matsumoto, K., Wakabayashi, J. and Liou, J.G. (2006a) Franciscan eclogite revisited: Reevaluation of the $P-T$ evolution of tectonic blocks from Tiburon Peninsula, California, U.S.A. Mineralogy and Petrology, 88, 243-267.

Tsujimori, T., Sisson, V.B., Liou, J.G., Harlow, G.E. and Sorensen, S.S. (2006b) Very-low-temperature record of the subduction process: A review of worldwide lawsonite eclogites. Lithos, 92, 609-624.

Wakita, K., Munasri, Sopaheluwakan, J., Zulkarnain, I. and Miyazaki, K. (1994) Early Cretaceous tectonic events implied in the time-lag between the age of radiolarian chert and its metamorphic basement in the Bantimala area, South Sulawesi, Indonesia. The Island Arc, 3, 90-102.

Wakita, K., Sopaheluwakan, J., Miyazaki, K., Zulkarnain, I. and Munasri (1996) Tectonic evolution of the Bantimala Complex, South Sulawesi, Indonesia, In Tectonic Evolution of Southeast Asia (Hall, R. and Blundell, D.J. Eds.). Geological Society of London Special Publication, 106, 353-364.

Whitney, D.L. and Evans, B.W. (2010) Abbreviations for names of rock-forming minerals. American Mineralogist, 95, 185-187.

Wunder, B. and Schreyer, W. (1997) Antigorite: high-pressure stabity in the system $\mathrm{MgO}-\mathrm{SiO}_{2}-\mathrm{H}_{2} \mathrm{O}$ (MSH). Lithos, 41, 213227.

Manuscript received September 7, 2015

Manuscript accepted May 5, 2016

Manuscript handled by Tetsuo Kawakami, Guest Editor 